\title{
PERLINDUNGAN HUKUM TERHADAP HAK WARIS ANAK ANGKAT DI INDONESIA
}

\author{
Lisa Carterina Kunadi \\ E-mail: carterina69@gmail.com \\ Mahasiswa S1 Program Studi Ilmu Hukum Fakultas Hukum \\ Universitas Sebelas Maret Surakarta \\ Diana Tantri Cahyaningsih \\ E-mail: dianatantri@yahoo.com \\ Dosen Fakultas Hukum Universitas Sebelas Maret Surakarta
}

\begin{abstract}
This article discusses the legal protection of adopted children for the inheritance rights of adoptive parents in the Civil Law system in Indonesia. Writing this law is a type of normative legal research that acts prescriptively. The research data is primary data and secondary data. Based on the results of research that can be known, the adoption of children carried out by adoptive parents will require that there is legal protection for the adopted child which is the right of the adopted child to obtain an inheritance from his adoptive parents. The results of the study explaining 4 Court Decisions that have issued these considerations are in accordance with the regulations reviewed in the perspective of Civil Law. The adopted child still has the right to get the inheritance from his adoptive parents.
\end{abstract}

Keywords: Legal Protection; Inheritance Rights; Adopted Children

\begin{abstract}
Abstrak
Artikel ini bertujuan untuk mengetahui perlindungan hukum terhadap anak angkat atas hak waris orang tua angkatnya dalam sistem Hukum Perdata di Indonesia. Penulisan hukum ini merupakan jenis penelitian hukum normatif yang bersifat preskriptif. Pendekatan penelitian menggunakan pendekatan Undang-Undang dan pendekatan kasus serta jenis data-data berupa data primer dan data sekunder. Berdasarkan hasil penelitian dapat diketahui, bahwa pengangkatan anak yang dilakukan oleh orang tua angkat akan mengakibatkan harus adanya suatu perlindungan hukum bagi anak angkat tersebut yang satunya adalah hak anak angkat untuk mendapatkan warisan dari orang tua angkatnya. Hasil penelitian menjelaskan bahwa berdasarkan 4 Putusan Pengadilan yang telah diteliti tersebut pertimbangan hakim sudah sesuai dengan peraturan perundang-undangan yang ditinjau dari perspektif Hukum Perdata. Anak angkat tetap mendapatkan haknya yaitu hak untuk mendapatkan warisan dari orang tua angkatnya.
\end{abstract}

Kata Kunci: Perlindungan Hukum; Hak Waris; Anak Angkat

\section{A. Pendahuluan}

Memiliki keturunan dalam suatu perkawinan merupakan suatu hal yang diimpikan dalam suatu keluarga untuk dapat meneruskan garis keluarga. Terdapat banyak hal yang mengakibatkan pasangan suami istri tidak memiliki anak kandung harus melakukan pengangkatan anak, namun banyak juga keluarga yang tetap melakukan pengangkatan anak meskipun sudah memiliki anak kandung. Indonesia merupakan negara yang sudah tidak asing lagi dengan hal pengangkatan anak, anak angkat merupakan suatu perbuatan hukum di dalam rangka hukum adat keturunan, apabila seorang diangkat atau didudukkan dan diterima dalam suatu posisi baik biologis maupun sosiologis (Muhammad, 2006: 32 - 35). Fahmi Al Amruzi berpendapat bahwa anak angkat dan lembaga pengangkatan anak termasuk persoalan yang actual di tengah-tengah masyarakat, tidak hanya pada masa sekarang tetapi sudah ada sejak masa prapenjajahan yang hidup dalam kehidupan masyarakat adat di nusantara (Al Amruzi, 2014 : 107 - 114). 
Peraturan mengenai pengangkatan anak di Indonesia sudah diberlakukan sejak zaman Hindia Belanda, dimana dalam Staatsblaad Nomor 129 Tahun 1917 mengatur mengenai pengangkatan anak untuk Warganegara Indonesia Keturunan Tionghoa. Pengangkatan anak yang boleh dilakukan hanya pada anak laki-laki saja dan mengakibatkan putusnya hubungan keperdataan antara anak yang diangkat dengan orang tua kandungnya, dan kedudukan anak angkat tersebut dipersamakan dengan kedudukan anak kandung oleh orang tua yang mengangkat sehingga ia berhak untuk mewaris harta kekayaan orang tua angkatnya. Staatsblaad yang pada mulanya khusus diberlakukan untuk masyarakat golongan Tionghoa yang ada di Indonesia, namun seiring berjalannya waktu masyarakat umum juga berpedoman pada Staatsblaad tersebut.

Pengangkatan anak juga menjadi bagian dalam adat kebiasaan masyarakat muslim di Indonesia dan sudah merambah dalam praktik melalui lembaga peradilan agama. Hukum Islam menentukan bahwa pengangkatan anak tidak memutuskan hubungan antara anak angkat dengan orang tua kandungnya, terutama dalam hal mewarisi harta peninggalan orang tuanya dan secara tegas ditentukan bahwa anak angkat bukanlah ahli waris dari orang tua angkatnya (Susiana,2011: 139- 148). Pemerintah juga mengeluarkan Instruksi Presiden Nomor 1 Tahun 1991 tentang Penyebaran Kompilasi Hukum Islam (KHI) yang di dalamnya mengatur mengenai anak angkat dimana anak angkat merupakan anak yang dalam pemeliharaan untuk hidupnya sehari-hari, biaya pendidikan dan sebagainya beralih tanggung jawabnya dari orang tua asal pada orang tua angkat berdasarkan Putusan Pengadilan.

Penulisan hukum ini penulis mengkaji beberapa putusan yang membahas mengenai anak angkat dan hak warisnya, dalam beberapa putusan tersebut berdasarkan keputusan hakim tetap mendapatkan hak waris meskipun pada masing-masing putusan hakim menimbang berdasarkan perspektif Hukum Perdata di Indonesia. Persoalan mengenai hak anak angkat untuk mendapatkan hak waris dari orang tua angkatnya merupakan persoalan yang umum ditemui dalam permasalahan hukum waris di Indonesia.

Berdasarkan uraian di atas, maka dalam artikel ini akan menganalisis perlindungan hukum anak angkat dalam hak waris di Indonesia.

\section{B. Metode Penelitian}

Metode dalam penulisan skripsi ini adalah menggunakan metode penelitian hukum normatif yang menggunakan data primer dan sekunder. Sifat penelitian dalam penulisan hukum ini bersifat perspektif atau terapan, penelitian preskriptif atau terapan obyek ilmu hukum adalah koherensi aturan norma hukum dan prinsip hukum, antara aturan hukum dan norma hukum serta koherensi antara tingkah laku dengan norma hukum (Peter Mahmud Marzuki, 2014 : 14).

Teknik analisis data menggunakan menggunakan metode silogisme yanng menggunakan pola berfikir deduktif. Metode deduktif berpangkal dari pengajuan premis mayor kemudian diajukan premis minor, dari kedua premis tersebut kemudian diajukan premis minor, dari kedua premis tersebut kemudian ditarik suatu kesimpulan atau conclusion (PeterMahmud Marzuki, 2014:89). Philipus M. Hadjon dalam pemaparannya mengemukakan bahwa di dalam logika silogistik untuk metode deduksi yang merupakan premis mayor adalah aturan hukum, sedangan premis minornya adalah fakta hukum. Dari kedua premis tersebut maka akan ditarik suatu kesimpulan atau conclusion (Peter Mahmud Marzuki, 2014:89).

\section{Hasil Penelitian dan Pembahasan}

Pengangkatan anak yang dilakukan tentunya akan menimbulkan perlindungan hukum bagi anak angkat tersebut. Perlindungan hukum menurut Philipus M. Hadjon dibagi menjadi dua yaitu perlindungan hukum secara preventif dan perlindungan hukum secara represif. Perlindungan hukum preventif memberi kesempatan pada anak tersebut untuk mengajukan keberatan ataupun 
pendapatnya sebelum suatu keputusan pemerintah dapat melanggar hak-hak anak, tujuannya adalah untuk mencegah adanya pelanggaran terhadap hak anak. Perlindungan hukum represif merupakan suatu perlindungan hukum untuk dilakukannya penindakan oleh pemerintah yang tujuannya adalah untuk menyelesaikan sengketa (Philipus M. Hadjono, 1987 : 20). Tujuan dari adanya perlindungan terhadap anak angkat adalah untuk memberikan perlindungan pada anak angkat agar hak-hak anak tersebut dapat terpenuhi.

Anak angkat sendiri perlu untuk dilindungi dikarenakan pada saat ini banyak terdapat modus kejahatan dari pengangkatan anak yang dilakukan oleh orang tua angkat dengan berbagai alasan ingin memiliki keturunan sebagai penerus dalam keluarga tersebut namun pada kenyataannya anak tersebut tidak diperlakukan dengan baik dan tidak dianggap seperti anak kandungnya sendiri (Oeke Reva Ade Pratiwi, 2014 : 5).

Bentuk perlindungan hukum waris anak angkat ditunjukkan dalam peraturan perundangundangan sebagai berikut:

a. Pengangkatan anak tidak diatur di dalam KUHPerdata sehingga lahirlah Undang-Undang mengenai Pengangkatan Anak yaitu Staatsblaad Nomor 129 Tahun 1917 yang menyatakan bahwa anak adopsi memiliki hubungan keperdataan secara hukum dan disamakan kedudukannya sebagai anak yang lahir dari orang tua angkatnya, sehingga dijadikan sebagai anak yang dilahirkan dari perkawinan orang tua angkat dan menjadi ahli waris orang tua angkatnya (Sintia Stela Karaluhe, 2016:167). Pengangkatan anak terdapat dalam SEMA No.6 Tahun 1983 yang pada intinya menyatakan bahwa setiap anak yang diangkat haruslah melalui jalur penetapan pengadilan, Undang - Undang Nomor 35 Tahun 2014 tentang Perubahan atas Undang-Undang Nomor 23 Tahun 2002 Pasal 1 angka 9 tentang Perlindungan Anak berbunyi: Anak angkat adalah anak yang haknya dialihkan dari lingkungan kekuasaan keluarga orang tua, wali yang sah, atau orang lain yang bertanggung jawab atas perawatan, pendidikan, dan membesarkan anak tersebut ke dalam lingkungan keluarga orang tua angkatnya berdasarkan putusan atau penetapan pengadilan. Kedudukan dan hubungan hukum yang demikian tentunya seorang anak angkat mempunyai hak mewaris atas harta waris orangtua angkatnya dengan memiliki hak waris sesuai legitieme portie atas segala bentuk harta waris dan sebagai ahli waris mutlak dari orangtua angkatnya sebagaimana ketentuan Pasal 852 KUHPerdata. Staatsblaad Nomor 129 Tahun 1917 mengenai pengangkatan anak mengakibatkan putusnya hubungan antara anak angkat dengan orangtua kandungnya. Staatsblaad memberikan pembatasan dari hak mewaris anak angkat yaitu anak angkat hanya menjadi ahli waris dari bagian yang tidak diwasiatkan Anak angkat dapat mewaris orang tua angkatnya tetapi yang terpenting tidak merugikan ahli waris lain yang ada. Undang-Undang Nomor 35 Tahun 2014 tentang Perubahan atas Undang-Undang Nomor 23 Tahun 2002 jo Pasal 4 Peraturan Pemerintah Nomor 54 Tahun 2007, pengangkatan anak tidak mengakibatkan putusnya hubungan darah antara anak angkat dengan orangtua kandungnya. Anak angkat tetap mewaris terhadap orangtua kandungnya dengan kedudukan hak waris sebagaimana menurut ketentuan Pasal 852 KUHPerdata. Sistem kewarisan yang dianut oleh KUHPerdata adalah sistem parental atau bilateral namun terdapat juga sistem pewarisan menurut wasiat (testament) sebagaimana ketentuan Pasal 875 KUHPerdata. Seorang anak angkat mempunyai hak mewaris dari orang tua angkatnya seperti halnya seorang anak kandung yang dilahirkan dalam perkawinan yang sah. Akibat hukumnya dalam pembagian harta warisan berlaku sama dengan anak kandung seperti tertuang dalam Pasal 852 KUHPerdata. Menurut Pasal 830 KUH Perdata: Pewarisan hanya berlangsung karena kematian. Undang-Undang mengenal dua cara untuk mendapatkan suatu warisan yaitu: secara abinstestato (ahli waris menurut Undang-Undang), di dalam Pasal $832 \mathrm{KUHPerdata}$ dan secara testamentair (ahli waris karena ditunjuk dalam suatu wasiat/ testamen) dalam Pasal 899 KUHPerdata. Pemilik kekayaan membuat wasiat dimana para ahli warisnya ditunjuk dalam suatu wasiat/testamen (Regynald Pudihang, 2015: 159).

b. Kedudukan Anak Angkat ditinjau menurut Kompilasi Hukum Islam (KHI) dalam pembagian harta warisan. Pada Kompilasi Hukum Islam (KHI) pengelompokan ahli waris diatur pada Pasal 
174. Kedudukan anak angkat menurut Kompilasi Hukum Islam (KHI) tetap dianggap sebagai anak yang sah berdasarkan keputusan pengadilan dengan tidak memutuskan hubungan nasab dengan orang tua kandungnya. Anak angkat menurut hukum Islam tidak berhak untuk mewarisi peninggalan orang tua angkatnya, dikarenakan pewarisan dalam Hukum Islam dasar pewarisannya disebabkan oleh 2 hal yaitu hubungan darah dan hubungan perkawinan. Jaminan bagi anak angkat dalam hal memperoleh harta orang tua angkatnya maka orang tua angkat dapat memberikan hibah atau dapat juga diberikan melalui wasiat pada anak angkatnya (Susiana, 2011:144 - 145). Pasal 209 ayat (1) dan (2) Kompilasi Hukum Islam (KHI) menjelaskan bagi orang tua angkat yang tidak menerima wasiat wajibah diberi wasiat wajibah sebanyak-banyaknya $1 / 3$ dari harta warisan anak angkat, terhadap anak angkat yang tidak menerima wasiat diberi wasiat wajibah, sebanyak-banyaknya 1/3 dari harta warisan orang tua angkatnya. Pendapat Nasution yang kedua secondly, generally between adopted children and adoptive parents creates legal consequences. Thus, in the above case there is or does not have a will, the grandchild (adopted child) is given as many as 1/3 of the inheritance of the adoptive parents (grandparents) yang diterjemahkan menjadi bahwa kedua, secara umum antara anak angkat dan orang tua angkat menimbulkan akibat hukum. Pada kasus di atas ada atau tidak ada wasiat, cucu (anak angkat) diberi wasiat wajibah sebanyak-banyaknya 1/3 dari harta warisan orang tua angkatnya (kakek dan neneknya), orang tua angkat (kakek dan neneknya) diberi wasiat wajibah sebanyak-banyaknya $1 / 3$ dari harta warisan anak angkatnya (cucunya). Namun hal ini perlu mempertimbangkan perasaan anak atau cucu lain dari orang tua angkat tersebut (Nasution, 2015:73).

c. Kedudukan anak angkat ditinjau menurut Peraturan Pemerintah Nomor 54 Tahun 2007 dimana peraturan tersebut meliputi pedoman dalam pelaksanaan pengangkatan anak dan juga hakhak yang dimiliki oleh anak angkat untuk mencegah penyimpangan yang pada akhirnya dapat melindungi dan meningkatkan kesejahteraan anak demi masa depan dan demi kepentingan terbaik bagi anak (Guza, $2007: 14$ ).

d. Kedudukan anak angkat ditinjau menurut Hukum Adat dimana sistem Hukum Adat merupakan sistem yang hidup dan tidak tertulis dalam bentuk perundang-undangan. Pembagian warisan bagi anak angkat jika ditinjau dari Hukum Adat maka hal tersebut tergantung pada Hukum Adat yang berlaku pada adat setempat yang berlaku dengan sifat kekeluargaan serta sistem kewarisan, misalnya Adat Jawa pengangkatan anak tidak memutus hubungan antara anak angkat dan orang tua kandung sehingga anak angkat mendapat warisan dari orang tua angkat dan orang tua kandungnya, sedangkan Adat Minahasa pengangkatan mengakibatkan putusnya hubungan dengan orang tua kandung sehingga hanya mendapat waris dari orang tua angkatnya dengan membawa nama keluarga baru tersebut.

e. Pengangkatan anak melalui Pengadilan adalah suatu bentuk perlindungan terhadap kedudukan hukum anak angkat, dikarenakan dengan adanya putusan pengadilan tersebut anak angkat memiliki status kedudukan yang sama dengan anak kandung dalam aspek pendidikan, kewarisan dan lain sebagainya (Mukmin, $2014: 67$ ).

\section{Simpulan}

Perlindungan hukum menurut Phillipus M. Hadjon dibagi menjadi 2 yaitu perlindungan hukum preventif yang tujuannya untuk mencegah adanya pelanggaran terhadap hak anak angkat dan perlindungan hukum represif yang tujuannya adalah menyelesaikan sengketa. Perlindungan hukum tersebut harus dilakukan, tujuannya adalah untuk melindungi anak angkat atas haknya mendapat waris dari orang tua angkatnya.

Berdasarkan perlindungan hukum preventif dinyatakan dengan adanya peraturan perundangundangan dalam perlindungan hukum anak angkat yaitu dalam KUHPerdata menyatakan tidak adanya aturan mengenai pengangkatan anak sehingga lahirlah Undang-Undang mengenai pengangkatan anak yaitu Staatsblaad Nomor 129 Tahun 1917. Staatsblaad membatasi bahwa anak 
angkat hanya menjadi ahli waris bagian yang diwasiatkan. Pasal 852 KUHPerdata menyatakan bahwa kedudukan dan hubungan hukum seorang anak angkat mempunyai hak mewaris harta orang tua angkat dengan mewaris hak waris sesuai Legitime portie atas segala bentuk harta waris dan sebagai ahli waris mutlak dari orang tua angkatnya.. Pada Pasal 830 KUHPerdata menyatakan bahwa pewarisan hanya berlangsung karena kematian. Pasal 913 KUHPerdata menjamin Legitime Portie, dimana anak angkat tetap dapat mewaris harta orang tua angkatnya asalkan tidak merugikan ahli waris lain. Berdasarkan Kompilasi Hukum Islam (KHI) kedudukan anak angkat menurut KHI tetap dianggap anak sah berdasarkan putusan pengadilan dan tidak memutus nasab dengan orang tua kandungnya. Anak angkat mendapat hak waris dari orang tua angkatnya adalah dengan hibah atau wasiat. Pembagian wasiat wajibah diatur dalam Pasal 209 ayat KHI dimana anak angkat yang tidak menerima wasiat diberi wasiat wajibah sebanyak - banyaknya $1 / 3$ dari harta warisan orang tua angkatnya dan orang tua angkat diberi wasiat wajibah sebanyak-banyaknya $1 / 3$ dari harta warisan anak angkatnya. Peraturan Pemerintah Nomor 54 Tahun 2007 bahwa adanya pedoman dalam pelaksanaan pengangkatan anak dan juga hak-hak yang dimiliki oleh anak angkat untuk mencegah penyimpangan yang pada akhirnya dapat melindungi dan meningkatkan kesejahteraan anak demi masa depan dan demi kepentingan bagi anak. Dalam Hukum Adat tergantung pada Hukum Adat yang berlaku pada masing-masing daerah, misalnya Adat Jawa pengangkatan anak tidak memutus hubungan antara anak angkat dan orang tua kandung sehingga anak angkat mendapat warisan dari orang tua angkat dan orang tua kandungnya, sedangkan Adat Minahasa pengangkatan mengakibatkan putusnya hubungan dengan orang tua kandung sehingga hanya mendapat waris dari orang tua angkatnya dengan membawa nama keluarga baru tersebut.

Berdasarkan perlindungan hukum represif dinyatakan dengan adanya putusan hakim yang menyatakan bahwa anak angkat mendapat hak untuk mewaris dari orang tua angkatnya, hal tersebut menunjukkan adanya perlindungan dan kepastian hukum bagi anak angkat atas harta waris.

\section{E. Saran}

Perkembangan praktek pengangkatan anak yang terjadi di masyarakat pada saat ini memerlukan adanya suatu peraturan perundang-undangan yang lebih mudah, jelas, dan tegas sehingga peraturan tersebut dapat lebih dimengerti oleh masyarakat serta hendaknya masyarakat lebih memahami bahwa anak angkatpun perlu dilindungi hak-haknya untuk mendapatkan waris dari orang tua angkat untuk menghindari adanya persengketaan antar keluarga.

\section{F. Daftar Pustaka}

Afnil Guza.2008. Peraturan Pemerintah Republik Indonesia Nomor 54 Tahun 2007. Jakarta: Asa Mandiri

Bushar Muhammad. 2006. Pokok-pokok Hukum Adat. Jakarta: Pradnya Paramita.

Hotnidah Nasution. 2015. "Penetapan Cucu sebagai Anak Angkat dan Implikasinya terhadap Masalah Waris (Determination of Wash as a Children's Lift and Its Implications on the Issue of Inheritance)". Jurnal Ahkam: Sharia Science Journal. Volume 17, Terbitan Nomor1. Jakarta: Fakultas Syariah dan Hukum UIN Syarif Hidayatullah.

Jean K. Matuankota. "Perlindungan Hukum terhadap Anak Angkat". Jurnal Sasi Vol. 17 No. 3 Bulan JuliSeptember 2011. Maluku: Fakultas Hukum Universitas Pattimura.

Karimatul Ummah. 2005. "Adopsi sebagai Upaya Melindungi Hak-hak Anak dalam Perspektif Hukum Islam”. Jurnal Hukum No. 29 Vol. 12 Mei 2005. Yogyakarta: Fakultas Hukum Universitas Islam Indonesia.

Muam'mar Qadavi Karim. 2013. "Penyelesaian Hukum terhadap Pelanggaran Notaris dalam Pembuatan Akta Otentik". Lex Privatum. Vol.1/No.4/Oktober/2013. Manado: Fakultas Hukum Universitas Sam Ratulangi. 
Muhammad Abdul Fattah Santoso. 2017. "Hak-hak Anak dalam Islam: Konsekuensinya bagi Peran Negara dan Masyarakat Sipil untuk Mengembangkan Pendidikan Ramah Anak (The rights of the child in Islam: their consequences for the roles of state and civil society to develop child friendly education)". Indonesian Journal of Islam and Muslim Societies. Volume 7, Nomor 1. Salatiga: Institute Agama Islam Negeri Salatiga.

Muhammad Fahmi Al Amruzi. 2014. "Anak Angkat di Persimpangan Hukum". Jurnal Masalah-Masalah Hukum Universitas Diponegoro. Volume 43, Nomor 1. Semarang: Fakultas Hukum Universitas Diponegoro.

Mukmin. 2014. "Perlindungan Terhadap Hak Anak Angkat". Lex et Societatis, Vol. II/No. 7/Ags/2014. Manado: Fakultas Hukum Universitas Sam Ratulangi.

Peter Mahmud Marzuki. 2014. Penelitian Hukum.Jakarta: Kencana.

Philipus M. Hadjon. 1987. Perlindungan Hukum Bagi Rakyat Indonesia. Surabaya: Bina IImu

Prabowo Setyo Aji. 2014. "Pelaksanaan Penerbitan Catatan Pinggir pada Akta Kelahiran sebagai Akibat Pengangkatan Anak dan Akibat Hukumnya (Implementation of Issuance of Edge Notes on Birth Certificate as a result of the adoption of children and their legal consequences)". Pandecta Research Law Journal, Volume 9, Nomor 2. Semarang: Fakultas Hukum Universitas Negeri Semarang.

Regynald Pudihang. 2015. "Kedudukan Hukum Hak Waris Anak Angkat Menurut Kitab Undang-Undang Hukum Perdata”. Lex Privatum, Vol. III/No.3/Jul-Sep/2015. Manado : Fakultas Hukum Universitas Sam Ratulangi.

Rusli Pandika S.H., LL.M., Dr. 2002. Hukum Pengangkatan Anak. Sinar Grafika: Jakarta.

J. Satrio, SH. 2005. Hukum Keluarga tentang Kedudukan Anak dalam Undang-Undang. Bandung: PT Citra Aditya Bakti.

Sebastian Pompe. 1987. "Perlindungan Hukum bagi Rakyat di Indonesia (De invloed van het adatrecht bij de toepassing van het strafrecht in Indonesie)". Bijdragen tot de Taal-, Land- en Volkenkunde.

Sintia Stela Karaluhe. 2016. "Kedudukan Anak Angkat dalam Mendapatkan Harta Warisan Ditinjau dari Hukum Waris". Lex Privatum, Vol. IV/No.1/Jan/2016. Manado: Fakultas Hukum Universitas Sam Ratulangi.

Soraya Siregar. 2017. "Akibat Hukum Pengangkatan Anak terhadap Harta Warisan Orang Tua Angkatnya pada Etnis Tionghoa”.Vol 3 No 2 Oktober 2017. Sumatra Utara: Jurnal Notaris Universitas Muhammadiyah Sumatra Utara.

Suharto.2014. "Hak Waris Anak Angkat Menurut Hukum Islam di Indonesia". Jurnal Studi Hukum Islam. Vol.1 No.2 Juli - Desember 2014. Jepara : Universitas Islam Nahdlatul Ulama Jepara.

Sumiati Usman. 2013. "Kedudukan Hukum Anak Angkat terhadap Waris". Lex Privatum, Vol.1/No.4/ Oktober/2013. Manado: Fakultas Hukum Universitas Sam Ratulangi.

Susiana, 2011. "Hak Anak Angkat terhadap Harta Peninggalan Orang Tua Angkat Menurut Hukum Islam". Kanun Jurnal IImu Hukum. Volume 55, Nomor 1. Aceh: Universitas Syiah Kuala.

Oeke Reva Ade Pratiwi. 2014. "Perlindungan Hukum bagi Anak Indonesia yang Diadopsi oleh Warga Negara Asing dalam Hukum Positif di Indonesia". Jurnal IImiah. Malang: Universitas Brawijaya. 